
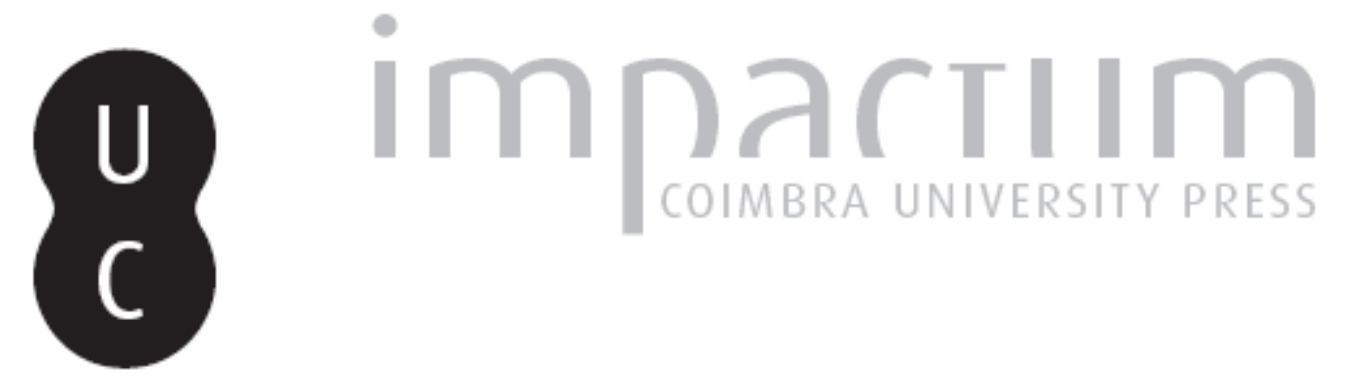

\title{
A música na literatura do império médio
}

\section{Autor(es): $\quad$ Canhão, Telo Ferreira}

Publicado por: Centro de História da Universidade de Lisboa

URL persistente:

URI:http://hdl.handle.net/10316.2/23527

DOI:

DOI:http://dx.doi.org/10.14195/0871-9527_21_4

Accessed : $\quad$ 26-Apr-2023 16:14:21

A navegação consulta e descarregamento dos títulos inseridos nas Bibliotecas Digitais UC Digitalis, UC Pombalina e UC Impactum, pressupõem a aceitação plena e sem reservas dos Termos e Condições de Uso destas Bibliotecas Digitais, disponíveis em https://digitalis.uc.pt/pt-pt/termos.

Conforme exposto nos referidos Termos e Condições de Uso, o descarregamento de títulos de acesso restrito requer uma licença válida de autorização devendo o utilizador aceder ao(s) documento(s) a partir de um endereço de IP da instituição detentora da supramencionada licença.

Ao utilizador é apenas permitido o descarregamento para uso pessoal, pelo que o emprego do(s) título(s) descarregado(s) para outro fim, designadamente comercial, carece de autorização do respetivo autor ou editor da obra.

Na medida em que todas as obras da UC Digitalis se encontram protegidas pelo Código do Direito de Autor e Direitos Conexos e demais legislação aplicável, toda a cópia, parcial ou total, deste documento, nos casos em que é legalmente admitida, deverá conter ou fazer-se acompanhar por este aviso.

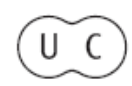



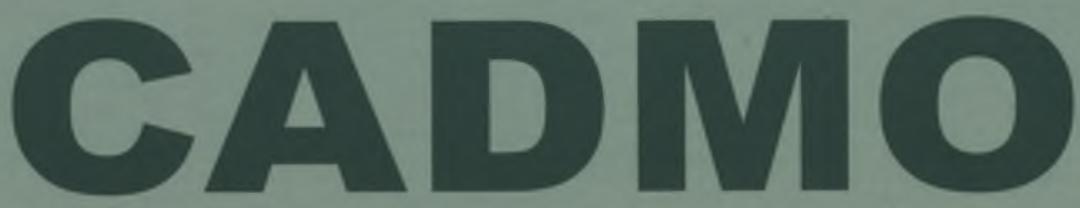

Revista de História Antiga

\author{
Centro de História \\ da Universidade de Lisboa
}

\title{
21
}

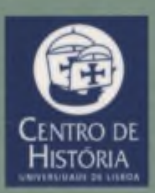

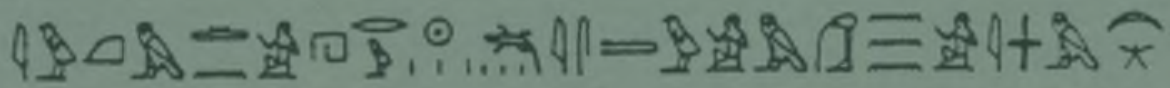

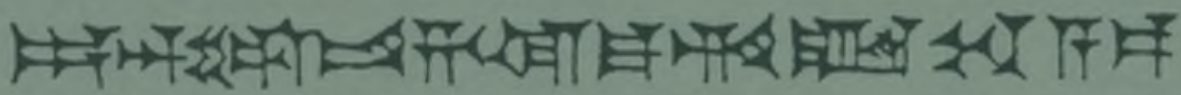

MHNIN AEI $\Delta \mathrm{E} \Theta \mathrm{EA}$ ПH$\Lambda \mathrm{HIA} \triangle \mathrm{E} \Omega$ 


\title{
A MÚSICA NA LITERATURA DO IMPÉRIO MÉDIO
}

\author{
TELO FERREIRA CANHÃO \\ Centro de História/Faculdade de Letras de Lisboa \\ telofcanhao@gmail.com
}

(Homenagem a Joel Ferreira Canhão.)

Por força dos antecedentes familiares, um aspecto do Egipto faraónico que sempre nos despertou alguma atenção foi a música. No Império Antigo constituíram-se os vários tipos de música que, depois, encontramos no Império Médio: a música religiosa, que se dividia em música de templo, música funerária e mistérios (origem do drama litúrgico); música de corte; música de circunstância (cerimónias solenes da corte, festas de jubileu, procissões dos deuses...); música utilitária (de magia e de trabalho) e música rural ${ }^{1}$.Vamos expor algumas questões sobre esta temática e procurar reflexos seus em textos do Império Médio.

Como bem se sabe, os Egípcios eram muito religiosos e a música não era mais do que uma maneira de se fazerem escutar pelos deuses. A música fazia parte da sua sensibilidade. Era uma arte divina e, em simultâneo, profundamente humana, que se impunha no quotidiano da vida egípcia fazendo parte da sua oração, dos seus cultos funerários e, sobretudo, juntamente com a palavra, servia para manter maat. Tendo como referência a qualidade técnica alcançada nas artes plásticas pelos Egípcios, a sua música terá sido elevada, cheia de profundo misticismo e "com regras que exibiam desenhos melódicos e rítmicos precisos, mas, antes de tudo, tipicamente egípcios. A execução desta música estava determinada por um estrito carácter ritual durante o qual nada era deixado ao acaso. Cada postura, gesto e movimento, estava rigorosamente fixado, criando uma estética estilizada para a prática vocal e instrumental, como 
se observa na arte ${ }^{2}$. A origem deste ritualismo era a sua concepção de «música» entendida como ordem do movimento ou «lei», dotada de um poder activo de regulação que não podia ser alterado, por ser parte integrante da cosmologia e do mundo dos deuses. Os sacerdotes, tanto os cantantes como os instrumentistas, "reconheciam na música esse poder mágico-religioso capaz de elevar o homem ao plano metafísico, que permitia ao músico uma busca espiritual em estado de consciência, uma via destinada à reflexão, ao aperfeiçoamento e à aquisição do domínio sobre si próprio. A serenidade dos movimentos constituía também um caminho ao reconhecimento e ao estado de maat» ${ }^{3}$. Isto não invalida o facto de se ter desenvolvido também uma música de cariz popular, cuja função era mais lúdica do que religiosa e os objectivos diferentes dos que se reconhecem a esta música erudita, como hoje a apelidaríamos.

$\mathrm{Na}$ realidade, é no Império Antigo que se encontram as bases da teoria musical egípcia, coincidindo com a construção das grandes pirâmides e o apogeu do culto solar. A música, longe de ser um simples entretenimento, estava, de facto, associada à cosmologia e à religião, integrando-se num contexto de proporções, ciclos rítmicos e medidas. Para os Egípcios a música era uma arte sagrada onde se integrava a dança e se fundiam o astronómico e o teológico. Havia o culto da voz e do canto, sendo pouco frequente a música exclusivamente instrumental. Aliás, é a música, como veículo da palavra sagrada, que justifica que no Império Antigo os músicos, de que se conservam muitos nomes, fossem sepultados nas necrópoles reais ${ }^{4}$.

Depois de ler obras como Music and Musicians in Ancient Egypt, de Lise Manniche, e, sobretudo, Musicologie Pharaonique. Études sur l'évolution de l'art musical dans l'Égypte ancienne, de Hans Hickmann, e La Música en la Era de las Pirámides, de Rafael Pérez Arroyo, a primeira de divulgação e as duas últimas de carácter científico no ramo da musicologia faraónica, não restam dúvidas de que não será a partir dos textos aqui apresentados que se poderá fazer uma história da música. Não é esse o objectivo. Aliás, qualquer displicente vista de olhos pelas últimas obras invocadas, mostra claramente que isso só é possível com recurso ao estudo da iconografia e dos instrumentos antigos. O que na realidade se pretende é pôr em relevo as alusões existentes nestes textos em relação à música, tentando demonstrar que a sua prática era essencial no Egipto faraónico na época em causa: o Império Médio.

Não são muitas as evocações relacionadas com música, mas mesmo assim são significativas. No texto As Admoestações de Ipu-uer o autor escreveu: 
«As mulheres músicas estão nos quartos no interior das salas de tecelagem e o que elas cantavam para Meret passaram a ser cantos fúnebres." $(4,12-4,13)$

\section{E mais à frente acrescenta:}

"Olhem, aquele que ignorava a lira, é (agora) senhor de uma harpa; aquele que não cantava para si próprio (agora) exalta Meret. " $(7,13-7,14)$

As Admoestações de Ipu-uer, um longo monólogo reflexivo sobre o difícil existencialismo num mundo em mudança, apresenta-nos estes quatro versos desprovidos de quaisquer conotações com templos ou ritos, falando de música em sentido lato. Porventura de música popular. Talvez por isso surja Merit e não qualquer outra divindade. Sabemos que Hathor, Ísis, Ihi, Tot ou Bés ${ }^{5}$, entre outros, eram deuses que, nas suas múltiplas atribuições, apareciam também ligados à música e aos instrumentos musicais, mas Merit, "A Amada», era a deusa da música. Sabemos, também, que havia vários tipos de música, mas como se depreende do texto, a música para Merit não devia ser fúnebre; pelo contrário, deveria ser alegre. Seria música de rua, de salões, até de alcova, mas nunca de recantos mais ou menos escondidos e de trabalho árduo, como eram as salas interiores ocupadas por teares. Embora houvesse também música de trabalho, tal como música fúnebre e ritual, depreende-se dos dois primeiros versos que a música de uma forma geral deveria ser alegre e festiva, o que só podia acontecer quando enquadrada por gente que a apreciasse despreocupadamente.

A introdução da lira neste texto dá-nos um elemento de datação importante: a lira é originária da Ásia e foi introduzida no Egipto no Império Médio. Esta comparação entre lira e harpa é basicamente uma comparação de tamanho e complexidade, para distinguir o pobre do rico: a lira é um instrumento pequeno, sóbrio e bastante portátil e a harpa, embora possa ter diversos tamanhos e formas, é grande, por vezes com ricas decorações, e de maior dificuldade de transporte. No fundo, parece que as mulheres músicas em tempos de normalidade tinham uma vida boa que perderam e as que nem tempo ou dinheiro tinham para a música, agora pareciam ser-Ihe dedicadas, provavelmente acompanhando-a com uma boa dose de lazer.

Deve no entanto referir-se que não era qualquer um que se tornava músico. A profissão de músico implicava uma longa aprendizagem e muita prática, quer fossem homens ou mulheres os executantes. Provavelmente, além dos músicos profissionais, nos lares mais abastados a educação 
das raparigas parece ter dado atenção à execução de harpa já desde o Império Antigo, tal como a espineta primeiro e o piano depois tiveram num passado recente. É que há muitos exemplos iconográficos onde a esposa toca harpa para o marido no quarto de dormir ou, noutros sítios menos íntimos, são as suas filhas que tocam esse instrumento na sua presença. Por vezes, cantavam enquanto tocavam ${ }^{6}$.

Que não era uma profissão para desprezar, podemos deduzir pela inexistência de qualquer referência na Instrução de Kheti, onde surgem as dezoito piores profissões que se poderia ter no Egipto. Antes pelo contrário, seria uma profissão conceituada, cujos executantes gozavam de privilégios. Como já referimos, no Império Antigo muitos músicos tiveram o privilégio de poder encarar a eternidade em necrópoles reais, onde ainda hoje se conservam os seus nomes. Aliás, a música devia ser considerada uma arte com uma certa elevação, com um certo destaque, pois quando as deusas Ísis, Néftis, Meskhenet e Heket, acompanhadas de Khnum resolveram mascarar-se para levar a cabo os partos divinos de Reddjedet, mulher de Rauser, foi de mulheres músicas, conforme podemos ler no quinto conto do Papiro Westcar, "O nascimento da V dinastia»:

\section{"As deusas (então) partiram}

depois de terem tomado a forma de mulheres músicas

e Khnum ia com elas transportando a bagagem.

Eles chegaram à casa de Rauser

e encontraram-no em pé com a tanga em desordem.

Elas deram-Ihe de presente os seus colares e as matracas.” (230-233)

Seria, portanto uma profissão muito digna, diríamos mesmo, digna de deuses. Além disso, os próprios instrumentos eram presentes divinos, pois foi com eles que presentearam o aflito Rauser. Acrescentemos que estes instrumentos tinham também uma certa simbologia: eram instrumentos associados aos cultos hatóricos, com uma forte influência na protecção da mulher, da maternidade e do parto, por um lado, mas também se ligavam à protecção e ao renascimento do faraó no Além ${ }^{8}$. As matracas, os colares menat e os sistros, o sekhem ou o sechechet, acompanhavam sempre as divindades e as sacerdotisas hatóricas ou a ela associadas. Na História de Sinuhe o próprio rei é presenteado com este tipo de instrumentos transportados pela esposa e pelas crianças reais, com a intenção de desejar longa e próspera vida ao faraó:

«Fizeram entrar as crianças reais

e sua majestade disse, então, à esposa real: 


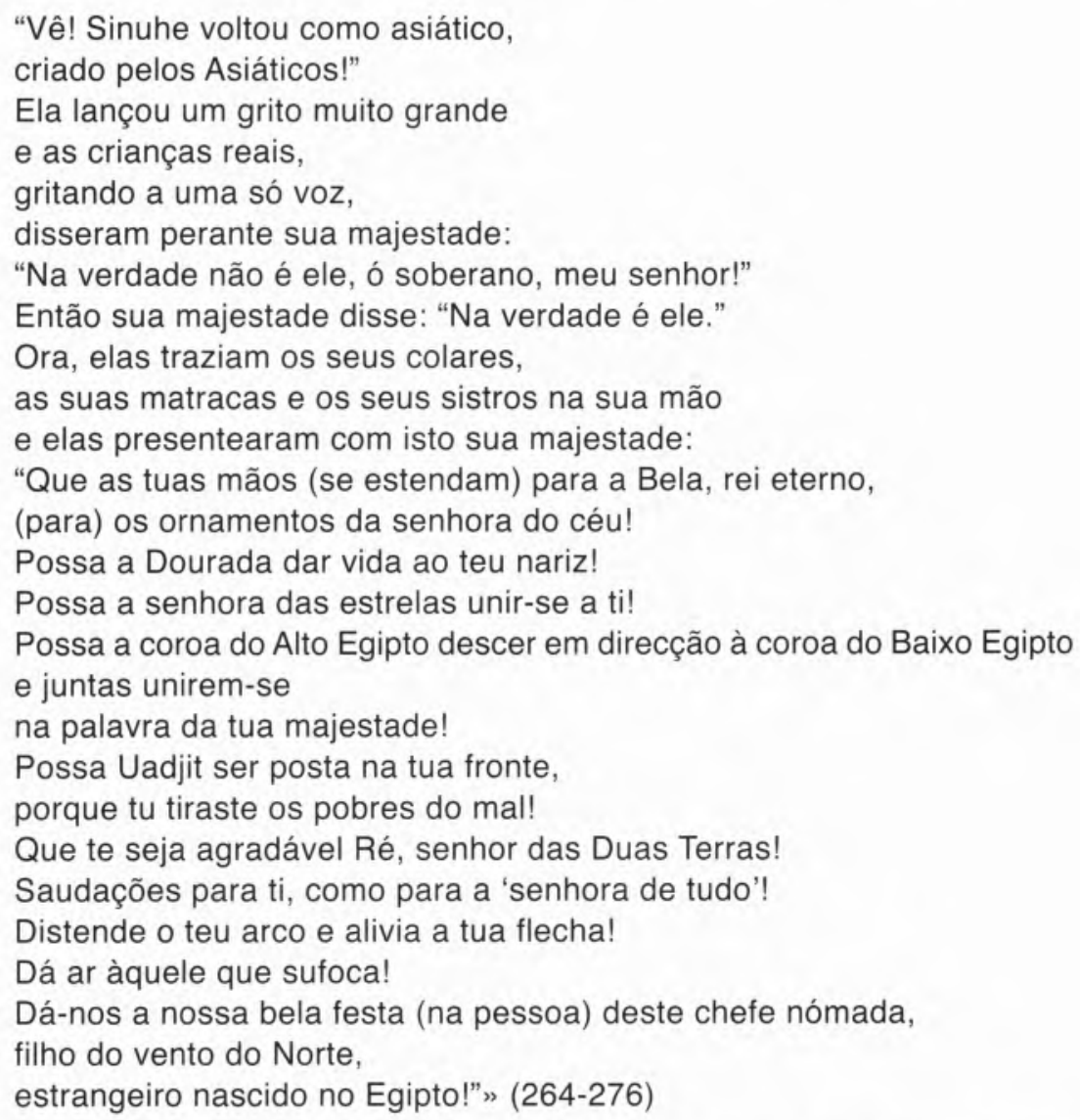

E tanta alegria e música proporcionada pelo agitar dos instrumentos do grupo dos idiofones ${ }^{9}$ tinha que culminar numa bela festa. Mesmo 0 culto diário e festivo dos templos era acompanhado de música. Para isso havia sacerdotes cantores e bailarinas e bailarinos especializados que utilizavam instrumentos musicais que pertenceriam aos próprios templos. Aparentemente, seriam os mesmos músicos dos templos que executavam a música na corte, conforme se depreende dos títulos funerários de alguns músicos que ocupavam simultaneamente cargos no templo e na corte. De igual modo, as diferenças entre uma festa no palácio ou numa festa privada em casa de um membro da elite, talvez se ficassem pela quantidade e qualidade dos músicos, embora se aceite que pudesse haver um número determinado para cada circunstância. A disposição dos músicos e as características dos sons e do elemento melódico deveriam ser muito parecidas. Mesmo nas manifestações lúdicas de música e dança na corte, 
parece ter havido um determinado ritual onde imperava a sobriedade dos movimentos, o estatismo, com origem num princípio estético que se baseava na busca de um "estado de perfeição". Conforme podemos observar em iconografia do Império Antigo, os músicos sentavam-se sobre uma tarimba baixa e nessa posição característica preparavam os seus espíritos emitindo sons que captavam a atenção dos ouvintes. Este momento de concentração dos músicos e do público, servia também para projectar na assistência "a elegância com que deviam ser tocados os instrumentos, de forma tal que, a música proporcionasse um prazer visual junto com o auditivo " ${ }^{10}$. Mantendo sempre uma afinação rigorosa e sem sair de regras estritas, a música instrumental começava com sons largos e moderados, e, quando era o caso, as danças começavam com grande lentidão. Dadas as características da arte egípcia, na sua música deve ter existido a variação mas não a improvisação.

Devido à grande importância que tinha a palavra na cultura egípcia, não existia reportório instrumental independente do vocal. Os instrumentos vinham em segundo plano como extensões da própria voz, acompanhando, repetindo ou interpretando a melodia cantada, umas vezes imitando as suas inflexões outras tentando dialogar com ela. Além dos já referidos idiofones, havia os membranofones, que incluíam diferentes tipos de tambores, os aerofones, constituídos por flautas oblíquas, clarinetes duplos e trombetas, e os cordofones onde se enquadravam os diferentes tipos de harpas. A harpa era um instrumento de luxo tocado tanto por homens como por mulheres. Embora a sua aprendizagem tivesse um grande grau de dificuldade e exigisse uma longa aprendizagem, já vimos que faziam parte da educação e hábitos das jovens das melhores famílias. No Império Antigo, só os homens tocavam a flauta e o clarinete duplo, mas a partir do Império Médio já é comum ver figuras femininas a tocarem estes instrumentos. A julgar pelos numerosos nomes de flautistas conhecidos, de todos os instrumentos, a flauta parece ter gozado de uma situação privilegiada. É provável que isso se tenha ficado a dever ao facto de os aerofones, tal como o canto, se alimentar da respiração humana, o alimento divino.

Voltando ao "Nascimento da V dinastia", quinto conto de Khufu e os Magos, podemos ver que, de facto, o mais importante era a voz que cantava e fazia música, e também dançava e aclamava. A voz vinha do saco dado às deusas e onde elas tinham escondido as coroas dos três reis. Aliás, dentro do saco ia uma festa digna de um rei no seu quarto:

«Então elas criaram três coroas reais, v. p. s., e puseram-nas no saco de cevada. 
Depois elas fizeram aparecer no céu uma tempestade de vento e chuva, voltaram-se em direcção a casa

e disseram: "Vamos pôr o saco de cevada

aqui numa sala selada,

para quando regressarmos ao norte (para) tocar música."

E puseram o saco de cevada numa sala selada.

Então Reddjedet purificou-se

com uma purificação de catorze dias.

Depois ela disse à sua serva: "A casa está abastecida?"

Ela respondeu: "Está abastecida de todas as boas coisas, excepto de jarros [de cerveja]. Eles não foram produzidos."

Reddjedet disse: "E porque é que, de facto, não foram produzidos os jarros

[de cerveja]?"

A serva respondeu: "Não há nada aqui para os fazer,

excepto o saco de cevada das mulheres músicas

que está na sala com a sua marca."

Reddjedet disse: "Desce e trá-lo para aqui.

Rauser logo Ihes dará o equivalente disso quando regressar."

A serva então foi, abriu a sala

e ouviu uma voz a cantar, a fazer música,

a dançar, a aclamar,

tudo o que era feito para um rei, no quarto.

Ela foi e contou tudo o que tinha escutado a Reddjedet.

Esta percorreu a sala mas sem encontrar o local onde ele [o barulho] era feito.

Então encostou a sua fronte ao saco

e descobriu que era feito no seu interior." (269-286)

Alguma iconografia do Império Antigo apresenta-nos conjuntos instrumentais mistos: no túmulo de Idu, em Guiza, podemos ver cinco harpistas acompanhados por um flautista e com a presença de um quirónomo ${ }^{11}$. Em Sakara, no túmulo de Mehu aparecem duas harpistas num registo e dois harpistas noutro. Em Dahchur, duas mulheres tocam harpa, um homem canta e outro toca flauta. Há outros exemplos ${ }^{12}$. Estes conjuntos instrumentais exibiam-se no interior dos palácios, onde, conforme se vê em algumas representações, se sentavam sobre um estrado de madeira que deveria servir de caixa de ressonância, ampliando o som das harpas e os golpes dos quirónomos no chão. Para marcar o ritmo havia palmas, matracas e sistros.

$\mathrm{Na}$ Instrução de Amenemhat I ao seu filho Senuseret, o defunto, Amenemhat, ao dirigir-se ao filho Senuseret I aproveita para apelar à humanidade para se perpetuar na eternidade fazendo-o da seguinte forma: 
"Minhas imagens vivas, meus herdeiros entre os homens, façam-me um canto fúnebre que nunca tenha sido ouvido em nenhum lugar.» $(1,7-1,8)$

Mais uma vez o apelo à música, neste caso introduzindo a ideia de ritual funerário. Não se pede uma música fúnebre, mas um canto fúnebre dando relevo à palavra. $\mathrm{E}$, obviamente, que o seu efeito se multiplicará eternamente caso seja um cântico exclusivo: despertará sem quaisquer equívocos a atenção das divindades e de todos aqueles a quem o cântico se destinar. Nas cerimónias dos rituais funerários entoavam-se cânticos, com ou sem acompanhamento instrumental, e dançava-se com acompanhamento de palmas. Isso ficou registado de forma muito clara na História de Sinuhe, no decreto que Senuseret I Ihe envia a pedir que regresse ao Egipto, dando destaque à importância de só no Egipto se poderem realizar as cerimónias fúnebres indicadas a um filho da ta-meri' ${ }^{13}$ :

Far-te-ão um cortejo funerário no dia da união à terra,

a máscara da múmia será de ouro,

a cabeça de lápis-lazúli,

o céu estará por cima de ti quando fores posto no sarcófago.

Serás puxado por bois

e precedido por cantores.

Será executada a dança dos mortos à entrada do teu túmulo, será recitada para ti a lista de oferendas

e farão sacrificios diante da tua mesa de oferendas. (192-196)

Devido à eficácia da palavra era dado maior destaque ao canto, pois os Egípcios acreditavam que nestes rituais a música era o veículo que transportava o ka a outra dimensão ou que o trazia de volta aos seus familiares nas celebrações em que estavam presentes. "Este canto, hst, por vezes acompanhado de harpa, era interpretado numa espécie de transe que aproximava o cantor do lugar onde estava o ka e, pelo que reflecte a iconografia, devia tratar-se de uma técnica altamente desenvolvida. Por esta razão tinham um carácter esotérico que fazia com que este reportório só fosse cantado por pessoas iniciadas, o clero especializado que se encarregava do culto funerário, das oferendas e restantes cerimónias necessárias à sobrevivência do ka no Além " ${ }^{14}$.

A esta música refinada e culta que encontramos na corte, nos salões da elite, nos templos e nas grandes manifestações religiosas, o povo seria alheio. Ele também terá conhecido a sua própria música, tal como vimos na primeira citação destas linhas do texto As Admoestações de Ipu-uer. 
O povo teria os seus momentos de cânticos, de danças e do ritmo das palmas e das matracas nas festas e nos momentos de alegria. Na própria cultura rural o pastor deveria cantar enquanto pastoreava o seu rebanho, os carregadores aliviavam-se do peso das suas cargas à custa de cantos curtos, os trabalhadores animavam-se nas suas árduas tarefas com cantos semelhantes aos que ainda hoje se podem ouvir no mundo rural egípcio, por vezes com acompanhamento instrumental. A iconografia de vários túmulos de Guiza e Sakara mostra exactamente quadros deste tipo: uns cortam com uma foice o trigo enquanto um músico entoa uma melodia acompanhado por outro músico que toca uma flauta. Mas é evidente que os relevos dos túmulos mostram músicos especializados, com uma formação de alto nível nas escolas dos templos ou da corte. Dos músicos rurais, músicos populares de ocasião que tentavam evidenciar esforços para tornar o seu trabalho mais leve, não temos nenhuma informação.

Um texto que pela sua apresentação parece talhado para ser cantado ou, no mínimo, declamado de maneira ritualista, é aquele que conhecemos com o título de Hinos a Senuseret III. A apresentação deste texto é, ao que sabemos, única. São três páginas em egípcio hierático que se lêem da direita para a esquerda: a primeira em colunas e as restantes em conjuntos de linhas. Nelas têm sido contabilizados seis hinos. Graficamente apresenta-se do seguinte modo:

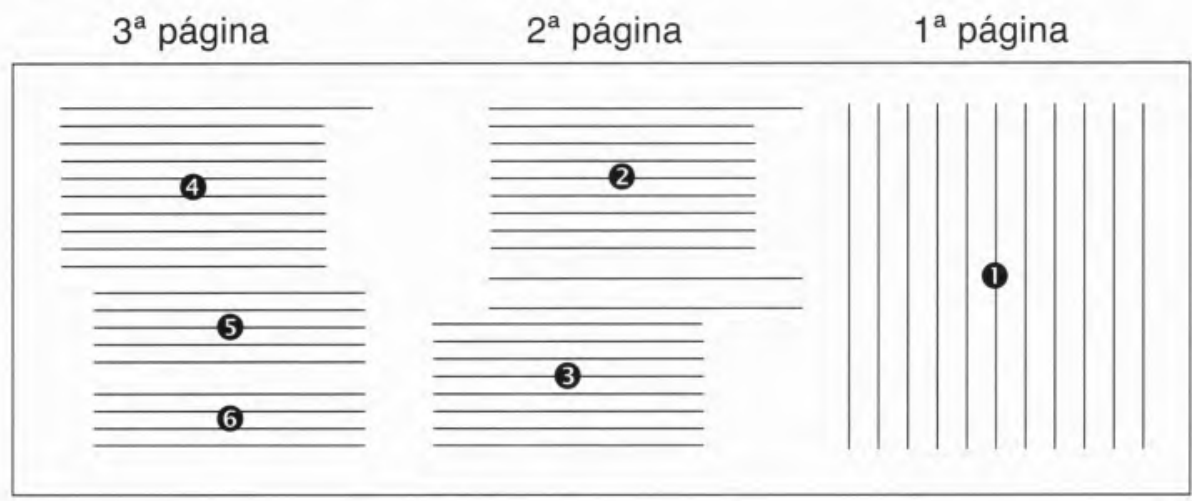

Há razão para estamos tão seguros desta divisão dos hinos? E da forma como seriam executados? Da primeira página não há nada a dizer: é uma página normal de onze colunas. Mas a segunda e a terceira páginas têm um grafismo curioso e original, claramente visível nos segundo, terceiro e quarto hinos. No segundo hino, o primeiro da segunda página, temos dez linhas em que as oito do meio estão alinhadas 
mais para o interior. Na primeira linha, saliente à sua retaguarda e das restantes linhas, temos uma anáfora, isto é, uma palavra ou grupo de palavras que devem ser repetidas nos versos seguintes para enfatizar 0 seu sentido ( $h^{\complement} w y$, «como se alegram»). É por isso que as restantes linhas começam mais recuadas como que deixando espaço para a repetição daquelas palavras. Se fosse hoje, cobriríamos esse espaço em branco com aspas de repetição! A décima linha começa com a palavra inyt, escrita a encarnado, que significa "refrão».

Sabe-se muito pouco sobre a execução dos hinos, por isso todas as ajudas para o esclarecimento desta questão são importantes. Sabemos que podiam ser entoados por cantores profissionais e por um coro, geralmente acompanhados de harpa ou, então, simplesmente recitados por sacerdotes. Podiam assim ser relacionados com o culto mas não eram considerados textos sagrados. Partindo da transcrição métrica de parte dos versos do segundo hino, Massimo Patané enreda-se numa explicação que, em nosso entender, parte de premissas incorrectas. Eis o seu caso ${ }^{15}$ :

A 1. $h^{\complement} w y$

B 2. idbwy m-nrw.k swsh.n.k-hrt.sn

A 3. $\quad h r s w s h-t 3 s ̌ . f ~ w h m . k-n h h$

A 4. $h^{\complement} w y$

B 5. d3mwn-tst rdi.n.k-rwd.sn

A 6. $\quad h r$ swsh-t3š.f whm.k-nḥh

A 7. $h^{\complement} w y$

B 8. imshw.k rdi.n.k-rnpy.sn

A 9. $h r$ swsh-t3š.f whm.k-nhh

A 10. hִwy

B 11. t3wy m-phty.k mki.n.k-inbw.sn

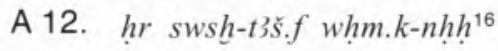

(6) 3. a letra A indica

(7) 2. os números entre

(3) parêntesis indicam a quantidade de acentuação. o coro e a letra B o solista.

Patané fixa-se apenas na segunda página desprezando os restantes hinos. Não pomos em causa a acentuação, nem o facto de $h^{\complement} w y$ poder constituir um verso, muito menos a pequena divergência de transliteração no quinto verso (lemos: d3mw.k stst rdi.n.k-rwd.sn, "as tropas que tu 
organizaste, por tu thes teres permitido o seu sucesso!») $)^{17}$ ou a ausência do $y$ na primeira palavra do oitavo verso (im3hyw, "veneráveis"). Mas questionamos o facto de, sem qualquer indicação ou sinal para isso, que o refrão "Hórus, que aumentaste a sua fronteira, possas tu repetir a eternidade" ( $h r s w s h-t 3 s . f w h m . k-n h h)$, ser repetido sistematicamente após todos os versos do segundo hino. No caso das anáforas o grafismo é claramente elucidativo! Além disso, porque seria este hino diferente de todos os outros, que apresentam anáfora mas não refrão? Acerca do posicionamento do refrão na décima linha da terceira página, ao contrário do que pensa Patané, julgamos que não seria para ser repetido após cada verso do segundo hino. Não há qualquer indicação ou sinal que leve a essa conclusão. Se tivermos em consideração a divisão em conjuntos de dez linhas/colunas, o facto de se encontrar exclusivamente neste local, fim do segundo hino do qual faria parte, seria apenas uma indicação para uma resposta em coro, ou para uma entoação direccionada para determinado sítio por parte do oficiante. Admitem-se outras duas hipóteses: se considerássemos os hinos com anáfora, que o refrão pudesse ser repetido no final dos hinos dois, três e quatro; se considerarmos as duas anáforas que se seguem, "como é grande o senhor para a sua cidade" (wrwy nb n niwt.f) e "ele veio" (ii.n.f), e relegarmos para segundo plano a divisão exacta das dez linhas, poderemos admitir que o refrão pudesse ser repetido após cada frase apenas no terceiro hino, por ser aquele em que a anáfora tem melhor concordância temática, ou nos terceiro e quarto hinos após cada frase, uma vez que a anáfora do segundo hinos, "como se alegram», não parece estar em plena concordância temática com o refrão.

Por outro lado, como é que se atribuem determinados versos a um solista e outros a um coro? A única indicação que permitiria isso é a palavra inyt, mas não inclui a anáfora nem estamos convencidos de que 0 refrão se repetisse em cada verso. Depois atribui a décima primeira linha a $A B$ (corifeu e coro) sem que se perceba porquê, e, no terceiro hino e na sua opinião, é a anáfora que é executada pelo coro e os dois versos de cada linha executados pelo solista. Esta décima primeira linha está claramente separada do refrão e encostada às restantes linhas do hino seguinte. Neste hino, embora saiba e afirme que a partícula proclítica não deveria ter acentuação própria, nem o substantivo pode ser acentuado conjuntamente com a partícula proclítica isw e a partícula enclítica $p w$, encaixa a sua teoria e avança com ela. Mesmo admitindo outras anomalias, nomeadamente no que respeita à acentuação das frases, acaba 
por fazer as correspondências métricas e concluir com a apresentação de uma isometria perfeita. Os seus números ${ }^{18}$ são:

$\begin{array}{cccc} & & \text { Versos } & \text { Acentos } \\ \text { Hino II } & \text { A } & 18 & 36 \\ \text { Hino III } & \text { B } & 9 & 27 \\ & \text { A } & 9 & 27 \\ & \text { B } & 18 & 36\end{array}$

Finalmente, também não comungamos da sua opinião de que a terceira página «testemunhe uma estrutura idêntica à primeira metade da segunda ${ }^{19}$. A décima linha da terceira página, ao contrário da décima linha da página anterior, que abre um espaço antes e outro depois de si, está bem encostada à nona linha e abre um espaço em relação à décima primeira linha. Para já não falar do que se convencionou chamar de quinto e sexto hinos que são diferentes em tamanho, arrumação e inexistência de anáfora. De igual modo, também a primeira página é totalmente diferente deste alinhamento. Serão os números um acaso? Este é um bom ponto de partida para futuras cogitações.

Para já e em conclusão, ao contrário de Patané, o posicionamento desta décima linha da terceira página leva a crer que não seria para ser repetido após cada verso do segundo hino. Não há qualquer indicação ou sinal que permita essa conclusão. Exclusivamente neste local, fim do segundo hino, seria apenas uma indicação para uma resposta em coro, ou para uma entoação direccionada para determinado sítio por parte do oficiante. Já a linha que se Ihe segue inicia-se também com uma anáfora que deve ser lida antes de cada um dos restantes nove versos do terceiro hino, que incluem ainda a partícula proclítica (isw), desta vez expressa em todos os versos que começam ainda mais recuados do que os do hino anterior. Talvez por ser uma partícula proclítica (variante de ist ou ist), que gramaticalmente encabeçam uma frase para Ihe dar relevo afirmativo ou exclamativo, não funcionasse como anáfora tendo que ser repetida antes de todos os versos deste hino. Também não é possível ver os versos em causa com duas anáforas consecutivas! Para isso seria apenas uma mais comprida e isw estaria junta com wrwy nb n niwt.f, o que não faria sentido, uma vez que as partículas proclíticas iniciam as frases, não sendo por isso lógico que fossem a sua conclusão.

$\mathrm{Na}$ terceira página deveria ser a mesma coisa para o quarto hino: temos também uma anáfora (ii.n.f) na primeira de dez linhas. O quinto 
e o sexto hinos não têm anáfora e começam recuados, no sítio onde começa a anáfora dos anteriores. São dez linhas, em que a primeira se perdeu totalmente, e as restantes só têm os primeiros dois terços da linha, com excepção das duas últimas que estão bastante danificadas. A única indicação visível de que podem ser dois hinos, é a notória separação que existe entre as cinco primeiras linhas e as cinco últimas. Outra indicação será temática: as primeiras cinco linhas dirigem-se aos ofertantes, enquanto as últimas cinco aparentam um elogio final a Senuseret III. De facto, os quinto e sexto hinos parecem não existir. Tal como no início há uma introdução, a primeira coluna da primeira página, aqui parece haver uma conclusão e não propriamente dois hinos. Até a apresentação gráfica é diferente da dos três hinos anteriores, para já não falar do primeiro que é apresentado em colunas. De qualquer modo, sobretudo devido ao estado em que se encontra esta parte do papiro, único local onde se apresenta este texto, apenas levantamos a dúvida mantendo a possibilidade de serem seis hinos.

Em busca de uma melhor compreensão desta área temática da egiptologia e da sua possível herança, damos de novo a palavra a Rafael Pérez Arroyo, cuja grande vantagem é não ser um egiptólogo que gosta de música, mas, pelo contrário, um musicólogo que gosta do Egipto faraónico, pois na realidade é licenciado em Musicologia e Direcção de Orquestra, pelo Real Conservatório de Música de Madrid. Ele reconhece aos Egípcios fortes responsabilidades na teoria e prática musicais. Diz ele a propósito do que apelida de herança do Vale do Nilo: "O reconhecimento por parte dos Egípcios de que a lei que rege a música, como arte intangível, é a mesma que rege a ordem no Universo, manter-se-á e consolidar-se-á na cultura faraónica até ao seu desaparecimento, servindo de ponto de partida à teoria grega da música. Deste modo, os Egípcios contemporâneos de Pitágoras eram os depositários de cobiçados conhecimentos de teoria e prática musicais, pelo que boa parte do que atribuímos à sua escola e a outros teóricos da música grega, como Cláudio Ptolomeu e Aristides Quintiliano que incluíram nos seus tratados conceitos de harmonia cósmica, podem ter raízes mais profundas no vale do Nilo muitos séculos antes. De facto, sabemos que alguns estudos citados por Plutarco no seu tratado Sobre Ísis e Osíris, quando faz algumas considerações relatam: "Dizem que Eudoxo recebeu instruções de 'Conufis o Menfita'; Sólon de 'Sonquis o de Sais' e Pitágoras de 'Enufis o de Heliópolis'. Posteriormente alguns elementos do sistema musical e cosmológico do antigo Egipto perdurariam na filosofia do neoplatonismo, em Porfírio e especialmente em Plotino, na mitologia das culturas do Mediterrâneo Oriental e na arte 
e na música da Idade Média europeia. Por exemplo, a essência desta ideia sobreviverá na concepção de uma natureza acústica da alma, Symphonalis est anima, reflectida por Hildegard von Bingen e que seria retomada pela escola romântica alemã no século XIX, tão influenciada pelo pensamento místico musical ${ }^{20}$.

Na realidade, houve no Egipto em diversas áreas uma ligação estreita entre ciência e técnica, como é fácil de depreender, por exemplo, das pirâmides. Ainda que ciência e técnica sejam coisas distintas, a primeira fundamentalmente teórica e a segunda prática, os Egípcios podiam não ter a primeira, ou pelo menos ela não estar ainda universalmente definida, mas eram verdadeiramente empíricos e demonstraram os seus conhecimentos mostrando que era possível fazer as coisas. O mais visível desta realidade é, sem dúvida, a sua arquitectura, sobretudo funerária, onde aplicaram uma perfeição geométrica e monumental que se manteve única até muito tempo depois da civilização faraónica ter terminado. Contudo, não tinham nem tratados nem quaisquer manuais científicos por onde se orientar. Mas conceberam e realizaram. E, aqui e ali, aparecem por vezes elementos que vão sendo pequenas pontas do gigantesco iceberg que foi a cultura egípcia faraónica.

O mais importante documento matemático egípcio que se conservou foi o Papiro Rhind ${ }^{21}$, cuja exemplar que chegou até nós é do Império Médio, ainda que tenha sido copiado de um original mais antigo. Este manuscrito mostra apenas uma pequena parte dos conhecimentos matemáticos egípcios aplicados a problemas concretos. Diz-nos que os Egípcios sabiam trabalhar com um sistema decimal de 1 a 100.000, que usavam correctamente todas as operações matemáticas, usavam também fracções, trabalhavam com as unidades de medidas lineares, de áreas e de volume e até utilizaram um caso particular do teorema de Pitágoras, muito séculos antes dos Gregos. Também conheciam e aplicavam diversos problemas de aritmética e geometria. Além disso sabemos que tinham profundos conhecimentos do ciclo solar e dos astros, em particular da estrela Sírio, do calendário e do ciclo das inundações. Tudo isto e muito mais, representa um conjunto de saberes que, não sendo organizados em ciência, eram no entanto o resultado de uma grande tradição de observação, reflexão e prática.

Partindo destas congeminações, Pérez Arroyo expõe e demonstra a existência de uma teoria da música no Egipto desde o terceiro milénio da nossa era. Mas os seus estudos vão muito mais longe e permitem-Ihe dizer: «Hoje podemos afirmar que uma parte dos princípios teóricos musicais da Hélade, especialmente os que constituíram o primeiro pitagorismo, 
descende em linha directa dos egípcios. Sem embargo, tem sido costume até há pouco eclipsar a existência de qualquer classe de ciência ou de filosofia antes dos Gregos, postura que actualmente já não é possível manter. Os historiadores e os músicos já reconheceram a ligação da ciência moderna e da nossa teoria da música com a helénica mas, a diferença da grande dívida é a que os Gregos reconheceram à civilização do Nilo no que concerne aos saberes matemáticos, astronómicos e musicais. Quiçá se deva a que ao carecer de meios para confirmar esta tradição se contentassem em negá-la ou, por uma mal compreendida defesa da Grécia, se esforçaram até ao impossível para negá-la. Mas a principal causa terá sido pelo desconhecimento dos hieróglifos e do seu significado que impediu, até serem decifrados por Champollion, um verdadeiro conhecimento desta cultura» ${ }^{22}$.

\section{Notas}

(1) R. PÉREZ ARROYO, La Música en la era de las Pirámides, pp. 101-106.

(2) Idem, pp. 101-102.

(3) Idem, p. 102.

(4) Idem, pp. 376-392.

(5) Modelo divino da feminilidade e das características associadas ao feminino (gentileza, amabilidade, ternura, sensualidade...), protectora das mulheres, Hathor era a deusa do amor, do prazer erótico e sexual, da alegria da dança, do canto e da música. Nesta última atribuição era portadora numa das mãos de um sistro, fosse o sekhem (sistro arqueado) ou o sechechet (sistro arquitectural), e o colar menat na outra, para ser agitado durante os rituais apropriados. Era ainda a deusa do álcool, da embriaguez e do êxtase associado ao álcool e, por isso, patrona dos ébrios. Por vezes era-Ihe associada a deusa Ísis, quando representada com o sechechet, o sistro arquitectural hathórico (um naos com duas volutas laterais sobre uma cabeça de humana com orelhas de vaca) numa das mãos, e, de igual modo, o colar menat na outra. Filha e esposa de Ré, terá concebido com ele Ihi (noutras descrições o pai era Hórus), considerado o deus da música, personificando o júbilo musical e apresentando-se de coroa real dupla, a pschent, trança infantil, sistro e colar menat. Tot tinha os instrumentos de sopro e de cordas sob a sua tutela, para além de ter sido o criador dos três tons de recitativo (poesia destinada à recitação com acompanhamento de música), conforme revela Diodoro da Sicília, acrescentando que esta criação vem desde a origem da música egipcia: um tom alto, um tom médio e um tom baixo, criados por Tot à semelhança das três cordas de uma harpa (ou lira). Ainda segundo Diodoro da Sicília, cada tom estaria relacionado com uma estação do ano: o tom alto com Akhet (o Verão), o tom médio com Peret (a Primavera) e o tom baixo com Chemu (o Inverno). Bés, o anão disforme, era protector das mulheres, das crianças e da vida familiar. Era ainda patrono da música, da dança, do prazer sexual e do divertimento em geral. Incentivando deuses e homens às manifestações de folia e festa, era representado a dançar e a tocar harpa ou pandeiro ( $\mathrm{J}$. C. SALES, As Divindades Egípcias, pp. 140, 177-178, 180-181, 319-320, 333-334; R. PÉREZ ARROYO, La Música en la era de las Pirámides, p. 114). 
(6) H. G. FISCHER, Egyptian woman of the Old Kingdom and of the heracleopolitan period, pp. 9-13.

(7) Ísis, protectora do parto e da infância, protótipo de esposa e mãe, mas, sobretudo uma espécie de mulher-modelo para qualquer das condições femininas (rainha, sacerdotisa, mágica, esposa, amante, irmã, mãe ou filha); Néftis era irmã de Ísis e estava, fundamentalmente, relacionada com o mundo dos mortos, contudo tinha também o epíteto de "Senhora da Casa" e foi mãe adúltera de Anúbis; Meskhenet, deusa do nascimento e do destino; Heket, deusa rã, da criação primordial e dos nascimentos; e Khnum, o demiurgo que modelou o homem a partir do barro (J. C. SALES, As Divindades Egipcias, pp. 134-143; 160-161; 292-300; 304-305; 326-327).

(8) Idem, p. 178.

(9) Instrumentos cujo som é produzido pela vibração do seu próprio corpo: matracas, sistros, chocalhos.

(10) R. PÉREZ ARROYO, La Música en la era de las Pirámides, p.103.

(11) $\mathrm{Na}$ iconografia do Império Antigo, sobretudo entre a IV e a VI dinastias, aparecem alguns homens e em certas ocasiões também mulheres, por vezes em grupos de dois ou de três em frente a um ou vários instrumentistas, a fazer determinados sinais com as mãos, nos quais musicólogos como Hickmann e Pérez Arroyo identificam indicações modais e rítmicas. São o resultado da sistematização levada a cabo pelos Egípcios para fixarem uma linguagem musical para a eternidade. É um sistema musical iconográfico que se encontra fixado nos relevos funerários. A palavra "quironomia" é empregue na musicologia há já bastante tempo e deriva do grego "quiros" que significa "mão", para se referir a uma antiga forma de dirigir ou indicar movimentos melódicos com as mãos, ligada às tradições musicais orais, especialmente no canto dos textos religiosos. Os autores helenísticos que falam deste saber asseguram que a origem há que procurá-la no Egipto ainda que tenha sido a Grécia a responsável pelo termo. Foi utilizada em Israel, em Bizâncio, inclusive em quase todas as civilizações antigas asiáticas incluindo Mesopotâmia, Índia, Tibet, Coreia, China e Japão. No Ocidente a quironomia foi aplicada ao canto chão, facilitando a memorização das melodias litúrgicas durante a Idade Média. No Egipto, a Igreja copta manteve esta tradição até há algumas décadas directamente herdada dos templos faraónicos. Simultaneamente na escrita hieroglífica, o braço e a mão eram os únicos determinativos para escrever, $8 \|$, hst (heset), os que "faziam música" ou ufaziam cantar 0 instrumento" que estava ao seu lado, sendo o Egipto o único lugar onde aparece a direcção quironómica de instrumentistas. Durante o Império Médio, os quirónomos quase desapareceram das cenas musicais, de junto do determinativo que Ihes havia sido comum e impôs-se a imagem do cantor com harpa ( $;$ ). Por fim no Império Novo, o termo hesete (hst) também perderá o seu significado simbólico convertendo-se numa palavra para "cantar" ou "recitar", completamente afastada do seu significado original (R. PÉREZ ARROYO, La Música en la era de las Pirámides, pp.120-121).

(12) Idem, p.104.

(13) "Terra Amada", o Egipto.

(14) Idem, p.103.

(15) M. PATANÉ, "La structure de l'hymne a Sesostris III (1)", em BSEG 8, pp. 61-65.

(16) Como se alegram

as Duas Margens com a tua terribilidade, tu aumentaste os seus bens!

Hórus, que aumentaste a sua fronteira, possas tu repetir a eternidade!

Como se alegram

as tropas organizadas, por tu Ihes teres permitido o seu sucesso!

Hórus, que aumentaste a sua fronteira, possas tu repetir a eternidade! 
Como se alegram

os teus veneráveis, por tu Ihes teres permitido o seu renascimento!

Hórus, que aumentaste a sua fronteira, possas tu repetir a eternidade!

Como se alegram

as Duas Terras com o seu poder, por tu teres protegido as suas muralhas!

Hórus, que aumentaste a sua fronteira, possas tu repetir a eternidade!

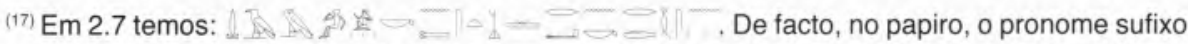
na segunda pessoa singular do masculino, . $k$ está lá, seguido do caracter G. N35 ( - ) onde devia constar o caracter $\mathrm{G}$. $\mathrm{O} 34(-)$ ) pois a palavra - $=1-$ existe como variante de verbo causativo da $3^{\mathrm{a}}$ inflexão stsi $i$, que significa "levantar", "originar", "criar", "angariar" ou "organizar". Como o exército nesta época não era profissionalizado, sendo os camponeses recrutados à medida das necessidades, seriam os soldados que tinham sido recrutados especificamente por Senuseret III (F. LL. GRIFFITH, (ed.), The Petrie Papyri. Hieratic Papyri from Kahun and Gurob, placa II; R. O. FAULKNER, A Concise Dictionary of Middle Egyptian, pp. 256 e 308; A. SÁNCHEZ RODRÍGUEZ, Diccionario Jeroglíficos Egípcios, p. 481; A. H. GARDINER, Egyptian Grammar, pp. 593 e 602).

(18) M. PATANÉ, "La structure de l'hymne a Sesostris III (1)», em BSEG 8, p. 65.

(19) Idem, ibidem.

(20) R. PÉREZ ARROYO, La Música en la era de las Pirámides, pp. 81-82.

(21) O Papiro Matemático Rhind foi encontrado perto do templo funerário de Ramsés II em Tebas, em meados do século XIX. Em 1856 foi comprado em Lucsor pelo britânico Alexander Henry Rhind, ao qual se deve o seu nome. Actualmente faz parte do espólio do Museu Britânico, com a designação BM 10057-8. No Museu de Brooklyn existem alguns fragmentos complementares deste papiro, que fóram adquiridos em Lucsor pelo americano Edwin Smith, no ano de falecimento de Rhind, 1863. Têm a referência $n^{\circ} 37.1784 \mathrm{E}$.

(22) R. PÉREZ ARROYO, La Música en la era de las Pirámides, p. 106.

\section{Bibliografia:}

CANHÃO, T. F., A literatura egípcia no Império Médio: espelho de uma civilização, Lisboa, tese de doutoramento em História (História Antiga), Faculdade de Letras da Universidade de Lisboa, 2010.

FAULKNER, R. O., A Concise Dictionary of Middle Egyptian, Oxford: Griffith Institute, Ashmolean Museum, 1996.

FISCHER, H. G., Egyptian woman of de Old Kingdom and of the heracleopolitan period, Nova lorque: The Metropolitan Museum of Art, 2000.

GARDINER, A. H., Egyptian Grammar, Oxford: Griffith Institute, Ashmolean Museum, $3^{\text {a }}$ ed., 1994.

GRIFFITH, F. LL. (ed.), The Petrie Papyri. Hieratic Papyri from Kahun and Gurob, Londres: Bernard Quaritch, 1898.

HICKMANN, H., Musicologie Pharaonique. Études sur l'évolution de l'art musical dans l'Égypte ancienne, Baden-Baden, Bouxwiller: Ėditions Valentin Koerner, 1987.

MANNICHE, L., Music and Musicians in Ancient Egypt, Londres: British Museum Press, 1991.

PATANÉ, M., “La structure de I'hymne a Sesostris III (1)", em BSEG 8 (1983), pp. 61-65. 
PÉREZ ARROYO, R., La Música en la Era de las Pirámides, Madrid: Editorial Centro de Estudios Egipcios, S. L., 2001.

SALES, J. C., As Divindades Egipcias, Lisboa: Editorial Estampa, 1999.

SÁNCHEZ RODRíguEZ, A., Diccionario Jeroglificos Egipcios, Madrid: Alderabán Ediciones, 2000. 